\title{
Where Do Social Ties Come From: Institutional Framework and Governmental Tie Distribution among Chinese Managers
}

\author{
Stan Xiao Li, ${ }^{1}$ Xiaotao Yao, ${ }^{2}$ Christina Sue-Chan, ${ }^{3}$ and \\ Youmin $\mathrm{Xi}^{2}$ \\ 'York University, Canada, ${ }^{2} X i$ 'an Jiaotong University, China, and ${ }^{3}$ City University of Hong \\ Kong, Hong Kong
}

ABSTRaCT This study identifies the societal institutional framework as the cause for the tie distribution issue - the sizes of ego-networks of social actors are unevenly distributed across social categories of these social actors. The analysis of 250 Chinese firms showed that managers employed by state-owned enterprises possess more governmental tie channels - conduits to get acquainted with government officials - than those employed by non-state-owned enterprises. Governmental tie channels completely mediated the relationship between ownership types and the number of government ties in the manager's social network.

KEYWORDS firm ownership, governmental ties, institutional framework, social tie channels, tie possession

\section{INTRODUCTION}

Recent research on social ties, or the connections possessed by social actors such as managers, has been dominated by a focus on the self-evolving nature of egonetworks. Ego-networks refer to the set of ties or connections that an individual reports to be important for achieving specific purposes, such as business development or career advancement (Wasserman \& Faust, 1994). The driving forces for tie evolution or changes in the composite set of connections within the network are proposed to be mostly nested inside the boundary of the social network (Kilduff \& Tsai, 2003), in other words, self-evolving. Two endogenous factors or factors internal to the social network - prior network configurations (Burt, 1992; Marsden, 1993) and social actors' prior collaboration routines (Li \& Rowley, 2002; Uzzi, 1996) - are the main explanations for tie evolution or changes within the ego-network. Once social ties have been started, social actors 
are subjected to forces internal to the existing ties when they consider updating their social connections.

Although the endogenous explanations identify many determinants of tie evolution or change in ego-networks, it may not be sufficient to answer one puzzle revealed by another line of network research: Different types of social actors possess different numbers of social ties. That is, some social actors have more of some ties than other social actors. This line of research further reveals that social categories (i.e., personal or social background) of the social actors may influence the sizes of their social networks. For example, male and female managers are shown to differ in the size and the degree of heterogeneity of their social networks (Ibarra, 1993). Disparities in ego-network size are also found across different foreign minority groups (Portes \& Sensenbrenner, 1993), business managers with different demographic backgrounds (Westphal \& Milton, 2000), and social groups with dissimilar social statuses ( $\operatorname{Lin}, 1999)$. Common in these findings is the observation that social categories, such as gender and race of the social actor, are associated with the sizes of their ego-networks - the extensiveness of social ties. The correspondence between background and network size is so pervasive that the human agency of social actors does not seem to matter in their efforts to increase their ego-network sizes (Entwisle, Faust, Rindfuss, \& Kaneda, 2007). Building on this line of research and focusing on China, our study aims to address the following central question: Why are ego-network sizes across social categories unevenly distributed? Specifically, why do managers in Chinese state-owned and non-state-owned enterprises differ in the number of ties who are government officers?

Our study proposes that forces that are either beyond the control of social actors or factors that may take a long time for social actors to modify are exogenous to these actors. We refer to the persistence of disparate ego-network sizes possessed by the members of different social groups as the tie distribution issue. Our study contributes to social network research by specifying the societal institutional framework as the exogenous force that shapes tie distribution. Whereas endogenous approaches acknowledge social actors' embeddedness in their own social network, we focus on the embeddedness of social actors in their institutional environment, an exogenous realm mostly beyond the managers' manipulation. We propose that the institutional framework is one potential cause of tie distribution because it confers core tie channels, serves as antecedents of social ties, both of which may be unevenly distributed across social categories. We propose that core tie channels mediate the linkage between social categories and tie distribution.

It has long been acknowledged that social connections are consequential not only in the U.S. but in other countries as well. We chose China as our research setting to examine our central question: How does the Chinese institutional framework confer one type of social tie, governmental ties, crucial for Chinese business managers, unevenly on two social categories - Chinese managers employed by state-owned enterprises (SOEs) and Chinese managers employed by non-state- 
owned enterprises (NSOEs)? China, a country with an institutional framework strikingly different from that of the U.S., is increasingly becoming a focal point for social network research (Bian, 1997, 2002).

\section{THEORETICAL BACKGROUND AND HYPOTHESES}

\section{Social Network Analysis and Tie Distribution}

The question, 'where do social ties come from', is a fundamental query in social network research (Gulati \& Gargiulo, 1999). To uncover tie genesis, two interrelated schools, both emphasizing endogenous factors, dominate this line of inquiry. The first school centers on the relationship configurations of a given network, arguing that prior relationship patterns induce the formation of new ties. A recent review (Smith-Doerr \& Powell, 2005) identifies several important concepts in this school, including structural equivalence (White, Boorman, \& Breiger, 1974), strength of tie (Granovetter, 1973), structural holes (Burt, 1992), and network density (Marsden, 1993). New ties emerge because the social relationship configurations that connected social actors in the past continue to impose its enduring influence in the future (Berkowitz \& Wellman, 1988).

The second school emphasizes the rationality of social actors - individuals who are capable of human agency. In their attempt to increase economic utilities, social actors construct new relationships when the marginal utility of adding new ties is positive (Doreian \& Stokman, 1997). A variation of this stream relaxes the assumption of 'maximizing utility' by replacing it with bounded rationality under imperfect information. This variation, which emphasizes the embeddedness of economic exchanges, maintains that the formation of social ties within a social environment is constrained by the factors nested within the environment (Granovetter, 1985). Various attempts by social actors to realize their objectives through the establishment of new social contacts commonly fail when they are confronted by uncertainties associated with their potential partners' capability and reliabilities. New social ties thus surface simultaneously with social actors' quest for information about their allies. The driving forces for new ties normally considered in this variation include prior repeated transactions and embeddedness in a community (Li \& Rowley, 2002; Uzzi, 1996).

A scrutiny of the above two schools reveals one commonality: Both approaches are preoccupied by two components endogenous to the focal network - its set of nodes (i.e., social actors and their human agency) and the arcs (or links) that connect these nodes (i.e., relationships that connected the social actors). Whereas the first school emphasizes the attribute patterns of the arcs or linkages, such as tie density, cohesion, and distance, the second school revolves around the nodes' (or ties') human agency constrained by forces circulating within the immediate neighbourhood of the nodes. The focal network is viewed as the self-sustaining engine 
shielded from the impacts of outer disturbances: 'organizational decision makers that play a crucial role in the formation of new strategic alliances rely on the network of past relationships to guide their future alliance decision' (Gulati \& Gargiulo, 1999: 1444-1445).

\section{Tie Distribution and the Anti-categorical Imperative}

Sociologists have long noticed that ego-network sizes are distributed unevenly across people occupying different societal categories. The tie distribution issue the ego-network sizes of social actors of certain social categories are larger than those of social actors of other social categories - was introduced about five decades ago by the six-degree linkage experiment (Milgram, 1967). The experiment shows that people higher up in the social hierarchy possess more social contacts and thus a larger network size. Disparities of ego-network sizes are revealed across genders, races, demographic backgrounds, and social positions (Lin, 1999; Portes, 1998; Reagans, Zuckerman, \& McEvily, 2004; Renzulli \& Aldrich, 2005; Westphal \& Milton, 2000). Social tie distribution is not a transitory issue. Social actors of the disadvantaged categories often attempt to alter their unfavourable condition embodied by a smaller network size although their efforts have not proved useful (Entwisle et al., 2007).

Endogenous approaches sidestep the tie distribution issue by discounting the utility of analysing social categories and focusing on the structure of the network instead, claiming that this latter approach: 'captures causal factors in the social structural bedrock of society, bypassing the spuriously significant attributes of people temporarily occupying particular positions in social structure' (Burt, 1986: 106). This structural approach in network research is aptly coined by Emirbayer and Goodwin (Emirbayer \& Goodwin, 1994: 1414) as the anti-categorical imperative: 'This imperative rejects all attempts to explain human behaviour or social processes solely in terms of the categorical attributes of actors, whether individual or collective'. Partly because of the imperative, it is no coincidence that a large number of social network studies render social categories into control variables (Kilduff \& Tsai, 2003).

We argue that the correspondence between social categories and egonetwork sizes highlights the impact of exogenous forces and discloses the limitations of the endogenous approaches. Recent studies that focus on endogenous factors and discredit the role of social categories are insufficient to embrace the rich institutional context, which are largely beyond social actors' means of modification. The neglect of social actor attributes amounts to negating the societal influences imposed upon social actors. Moreover, the extant research using the endogenous approach fails to pinpoint the ultimate cause leading to the tie distribution issue. We maintain that certain social groups are disadvantaged by the institutional framework because the framework is not facilitative for these groups 
to possess core tie channels, which are conduits for the materialization of social relationships.

\section{Chinese Institutional Framework}

Economists define a society's institutional framework as 'the set of fundamental political, social and legal ground rules that establishes the basis for production, exchange and distribution' (Davis \& North, 1971). The institutional framework provides formal and informal 'master rules' that guide social actors' interactions. It facilitates or legitimizes certain economic transactions and social exchanges, but constrains or entirely forbids other behaviours. The societal institutional framework can be partitioned into several pillars: the state, markets, democracy, family, and religion (Friedland \& Alford, 1991).

The Chinese institutional framework overwhelmingly prefers the state pillar to other pillars, such as the market pillar. The Chinese government remains the ubiquitous entity that acts as not only the judge of but also as the participant in market transactions. It deploys directives to legitimize the public property rights and restrains private property rights, and had long steered laws and regulations in ways that favour the legitimacy of SOEs (Scott, 2000). It was only in 2007 that the People's Congress of China (中国人民代表大会) (PCC) passed legislation to formally recognize private property rights. In 2008, SOEs and NSOEs in China employed 42.682 million and 79.040 million people, respectively (China National Burcau of Statistics, 2009). SOEs have long been one prominent source of employment and a major ownership type. The legitimacy and prevalence of public ownership led to stratification among Chinese business managers (cf. Gilbert \& Kahl, 1993): Along the ownership status of their employers, SOE managers versus NSOE managers are a pronounced social category partition. Many managers view the ownership type of their employers as one defining component of their self-identities (Dickson, 2003).

We argue that facilitating economic transactions is subordinate to the primary aim of ensuring political domination by the Chinese government in the Chinese institutional framework. In order to safeguard its power base and ensure its own survival, the Chinese government has retained its monopoly over two production input factors vital to any society: land and business credits (Sun, Wright, \& Mellahi, 2010). Private ownership of land is forbidden by law. Firms have to purchase the right to use land for a limited period of time from the government, the sole supplier of the collectively owned land. However, property rights regulations in general and land regulations in particular are among the least clarified legal domains. The Chinese government also dominates the markets for corporate equities, bonds, and bank loans, while foreign banks remain peripheral. The government pressures local banks to provide preferential loans to some SOEs that are deemed key enterprises by the government (Zhang \& Keh, 2010). 
Figure 1. Social categories and governmental tie distribution

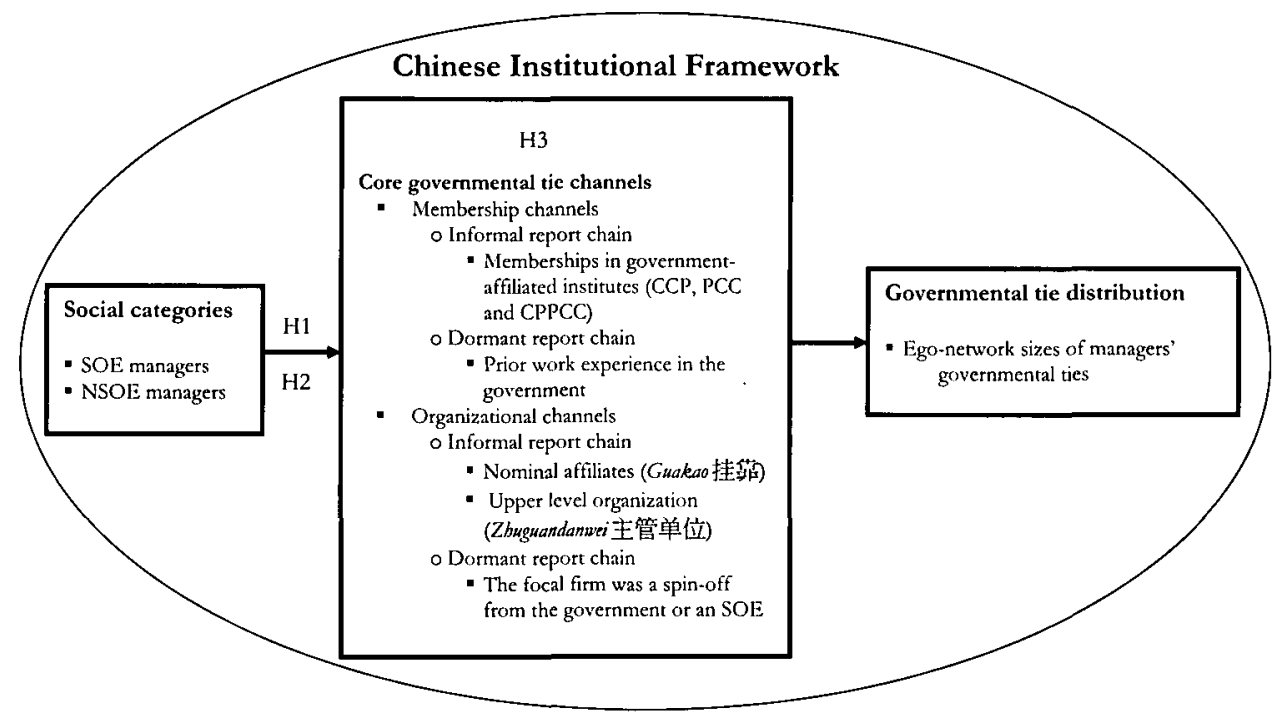

The Chinese institutional framework fails to provide the same level of clarity on regulations and hence market-oriented protection to firms as does the U.S. institutional framework (Peng, 2003). This deficiency is due to the lack of a clear definition of property rights, an inadequate judicial system to safeguard business contracts, and the domination of the Chinese government in the labour and raw materials markets. Impersonal business transactions thus fall short of being widespread in China because drafting and executing comprehensive business contracts are bound to incur high transaction costs when the imperfections in the Chinese institutional framework prevail (cf. North, 1990). The Chinese institutional framework compels Chinese business managers to cultivate a network of interpersonal connections, referred to as guanxi in China (Yang, 1994), with the most powerful regulators and players in the Chinese economy - Chinese governmental officials. Chinese managers cultivate governmental ties to increase predictability in business deals, thwart the advances made by business rivals, gain access to public projects and political prestige, and pre-empt the high costs of arbitration or haphazard court procedures due to unsuccessful business deals. We summarize our theoretical model about the role of the Chinese institutional framework in Figure 1.

\section{Core Governmental Tie Ghannels}

The Chinese institutional framework not only partitions business managers into two salient social categories - SOE managers versus NSOE managers - it also structures governmental tie channels. We define a governmental tie channel as an avenue used by managers to socialize with a governmental official. For example, 
when a manager and a government official both go to a restaurant that is hosting a party, this restaurant is a governmental tie channel through which a governmental tie potentially can occur. Governmental tie channels can be many things, including places, groups, associations, and organizations. These channels provide spaces to bring managers and government officials together and potentially compel them to interact.

There are two types of channels, peripheral channels and core channels. The restaurant mentioned above is a peripheral channel because it is a transient avenue that temporarily brings managers and officials together. In contrast, core governmental tie channels are institutionalized avenues that regularly allow governmental officials to interact with other people at these avenues. One example of core channels is the Chinese Communist Party (中国共产党) (CCP). The CCP recruits both governmental officials and non-governmental officials (e.g., managers) as party members. The party members are exposed to opportunities to become friends because of the activities organized by the CCP and its related organizations. Core governmental tie channels are stable, quasi-permanent valves that control the presence of options and possibilities for the emergence of a governmental tie.

Although tie channels precede and induce social relationships, the distinction between tie channels and social ties has been given insufficient attention in the extant literature. For example, Galaskiewicz and Burt (1991) and McPherson and Rotolo (1996) equate people's memberships in non-profit organizations or voluntary groups to the social ties among them. We make the distinction that a nonprofit organization is a social channel, whereas the relationship among two members is a social tie. Although equating tie channels to social ties for these studies are instrumental in parsimoniously surveying social relationships, in other cases it is problematic. The former is the antecedent of the latter, and there is no strict one-on-one correspondence between the two (Feld, 1981). It is possible that a tic channel may fail to lead to a social tie.

Meyer and Rowan (1977) posit that the emergence and survival of organizations dramatically reflect the myths of their institutional environment, and these organizations embody practices and procedures defined and legitimized by the societal institutional framework. Specifically, the Chinese institutional framework shapes core tie channels and is a powerful force in affecting the allocation of critical resources, such as legitimacy, publicity, licenses, and financial support to these channels (Batjargal, 2007; Hitt, Ahlstrom, Dacin, Levitas, \& Svobodina, 2004). If some social channels are aligned with or even conducive to the perpetuation of the societal institutional framework, these channels receive these resources more easily and are more likely to become core channels.

Research in institutionalism is consistent with the notion that the appearance of core tie channels is shaped by societal institutions. It is argued that the emergence of social ties is by no means a random process (Silver, 1990; Zuckerman \& Sgourev, 2006). DiMaggio and Powell (1983) maintain that the societal institutional frame- 
work largely dictates the social hierarchy, which in turn creates a core and peripheral structure for organizations. Few existing social network studies have explicated the role of the institutional framework in core tie channels. A notable exception is the study by Volker and Flap (1997), which shows that as Communist ideology promotes equality of all citizens, the former German Democratic Republic used a type of tie channel, social housing, to promote friendship among people from different social classes.

In summary, core governmental tie channels possess three characteristics. First, they are stable, long-term avenues for social actors to become acquainted with one another. The stability of these channels is safeguarded by the endorsement and financial support received from the dominant social players in the societal institutional framework. Second, although there are possibly numerous peripheral channels for governmental ties, only a limited number of core governmental channels exist in China. The latter are usually created directly by the most dominant defender of the Chinese institutional framework - the Chinese government - and are awarded high social prestige accordingly. Third, from the perspective of Chinese managers, the possession of core governmental tie channels is a critical success factor for doing business in China. Vital information, such as information about land and financial resources, readily circulates among people who frequent these core channels. In the following sections we categorize these core tie channels and discuss them in detail.

Membership channels - informal report chain. A major form of Chinese managers' individual governmental tie channels is their membership in key governmentaffiliated institutes that are erected directly by the Chinese government to uphold the political dominance of the government. Three pillar institutes in China are the CCP, PCC, and the Chinese People's Political Consultative Conference (中国人民政治协商会议) (CPPCC). The CCP is the ruling party, and the PCC is the Chinese legislative branch. The CPPCC is unique to China and has no equivalent counterpart in the West. The CPPCC, defined as a consultative organ, takes part in consultations of China's basic policies and important issues in political, economic, cultural, and social affairs. There are national, provincial, and county levels of PCCs and CPPCCs, whose members convene once every year and can serve for more than one 5 year term. Between conventions, a small number of PCC and CCPPC members constitute the year-round Standing Committee of PCCs and CCPPCs, respectively. The current national-level assemblies of PCC and CCPPC have about 3,000 and 2,000 members, respectively. It should be noted that although the real power resides in the CCP, the $\mathrm{PCC}$ and the $\mathrm{CPPCC}$ provide real networking opportunities during which thousands of people from all over China gather together regularly to socialize and attend a multitude of functions. ${ }^{[]]}$

The Chinese government incessantly absorbs CCP members from all social spectrums, and the CCP remains one of the most important institutions from 
which the government recruits future officials. The PCC and the CPPCC are important avenues for the Chinese government to approach, appease, and reward grass roots leaders. The government strongly influences the selection of PCC and CPPCC members. A significant portion of PCC members are current or retired governmental officials. Those not from the government are nominated by the government from as many social spectrums as possible, including representatives from all major ethnic minorities, from both genders, from every province, autonomous region, or major municipalities, and from all major industries. PCC constituencies therefore are designed to mimic the Chinese social strata. It is not surprising that in recent years more managers from NSOEs have been selected to PCCs, because NSOE managers have gradually become a legitimated social category (Dickson, 2003). Overall, the CCP and the PCC target NSOE managers as tokens, and more actively recruit SOE managers so as to consolidate their power. While a large portion of CPPCC members are also current or retired governmental officials, the remainder are nominated by the government mainly from leaders of other political parties, leaders of major religions, leaders of mass organizations (e.g., unions), and people without political party affiliation. Hence, the membership of CCPPCs is designed to mimic the political and religious composition of China.

From the perspective of the members of the CCP, PCCs, or CCPPCs, membership involves reporting chains through which members can voice their suggestions to the government. These are informal report chains because they are outside the government hierarchy and are infrequently invoked. From the perspective of the government, the CCP, PCCs, and CCPPCs are used to enforce the political legitimacy of the government and consolidate its power base. The government and its organs commonly appoint CCP members as CEOs of SOEs (Li, 1998). SOE managers are commonly sympathetic to or support the government because the government is the ultimate shareholder of their firms. In addition, the Chinese government regards SOEs as the pillar crucial for its economic policies and common interests. It is no coincidence that on average the Chinese government prefers to interact with SOE managers, in comparison with NSOE managers.

Membership channels - dormant report chain. The most utilized instrument for the Chinese government to consolidate its power base is the Chinese government itself. Many Chinese managers are former government officials and their work experience in the government is thus another type of individual-level channel that we refer to as the dormant report chain. For example, in the 1990s, the State Council of the Chinese government initiated several rounds of downsizing at different levels of the government. Although many of the laid-off officials were asked to retire, the Chinese government commonly relocated those who involuntarily left the government system to existing SOEs. In addition, the government formed new SOEs specifically to provide employment for the laid-off officials (Dickson, 2003). 
Some managers in NSOEs also possess government experience. Since the 1990s, some SOEs have been privatized and have become NSOEs. Since the mid-1990s, public sector employees have started to recognize the potential financial rewards from the private sector. As a result, some government officials voluntarily quit their government positions. Although many joined existing SOEs or founded their own SOEs, some former officials joined NSOEs or started their own NSOEs. However, NSOE managers who possess government experience are not widespread, as the majority of NSOEs were founded by non-government officials.

Combining all of the above examples, we refer to both the membership in CCP, PCC, and CCPPC and prior governmental experience as membership tie channels. We propose:

Hypothesis 1 (H1): SOE managers will have more government membership channels than will NSOE managers.

Organizational channels - informal report chain. Because the Chinese government remains an insurmountable entity in economic transactions, many Chinese firms voluntarily subject themselves to the hierarchical leadership of the Chinese government. One type of hierarchical report chain is one in which a Chinese firm, an SOE or an NSOE, is referred to as a xiajidanwei (下级单位) (literally 'lower-level organization'). From time to time, a xiajidanwei answers to the directives from a zhuguandanwei (主管单位) (literally 'upper-level organization'), which is either a governmental organ (e.g., state ministry, provincial bureau) or another SOE. The upper-level organization has the authority to enforce governmental regulations on the lower-level organization, such as worker safety regulations and licensing requirements. It is common for an upper-level organization to extract yearly management fees from a lower-level organization and in some cases the upper-level organization can influence the selection and appointment of the top management teams of the lower-level organization. However, in reality, the upper-level organization usually refrains from interfering with the long- and short-term strategies of the lower-level organization. Therefore, we refer to the institutional arrangement between a lower-level organization and an upper-level organization as an informal report chain. It should be noted that although in some cases, firms, either SOEs or NSOEs, of certain sectors have to have an upper-level organization because of regulations, most lower-level organizations voluntarily subject themselves to upperlevel organizations for a variety of reasons, including political protection and avoidance of extortion from other government organs (Sun et al., 2010).

Another type of interorganizational informal association, referred to as guakao (挂靠) (literally 'nominal, rather than actual, affiliates'), is that a focal firm, either an SOE or an NSOE, signs a contract with a governmental organ or another SOE. The contract specifies that the focal firm pays a fee to the governmental organ or the other SOE. In return, to outside stakeholders the focal firm can claim to be a 
branch of or affiliated with the government. This claim enables the focal firm to submit bids for some large projects that are usually reserved for organizations with an affiliation with the government, to obtain certain restricted business licenses, and to gain access to some advantages controlled by the governmental organ or the other state-owned organization (e.g., distributional channels or technology platforms). It is uncommon for the governmental organ or the other SOE to interfere with the long- and short-term strategic issues and appointment of the top management team of the focal firm. These were also referred to as 'red hats' in the early township and village enterprises (Chen, 2007).

The organizational channels created by zhuguandanwei and guakao allow business managers of a focal firm to gain legitimacy in the eyes of outside stakeholders, obtain political protection, and shield themselves from extortion by other organizations. On average SOEs are likely to be more willing to and more costefficiently maintain their organizational channels (e.g., zhuguandanwei and guakao) than NSOEs because SOEs have a deeper understanding about the government. SOE managers are also less concerned about paying the yearly 'management fees' so as to establish the guakao and/or zhuguandanwei channels, because the fees are not paid from their own pockets. In comparison, managers in NSOEs care more about the bottom line than their counterparts in SOEs, and are less willing to pay the fees.

Organizational channels - dormant report chain. Many SOEs and some NSOEs were former spin-offs from governmental organs or other government-owned organizations. Starting from the mid-1990s, to reduce the bloated headcount, several government ministries were merged or disbanded. The downsized government officials were commonly spun-off by the government to form new SOEs, and in some cases were encouraged by the government to start their own NSOEs (Sun et al., 2010). Later on, some spun-off SOEs were totally or partially privatized. Another type of spin-off is the spin-off from SOEs. In the early 1980s, many large-scale SOEs not only had for-profit operations, but also performed certain regulative roles (c.g., distribution of import and export quotas). As the economic reforms in China deepened, the not-for-profit operation arms of these large SOEs were spun-off to form stand-alone SOEs, and a small portion of these spun-off SOEs were later privatized.

Because the hierarchical report chains between the spun-off firms and the Chinese government were terminated when these firms were spun-off, we refer to the status of being a spin-off from a government organ or a government-owned organization as a dormant report chain. The dormant report chain is a form of organizational imprint, and its legacy has long-term influences on the organization (Stinchcombe, 1965). Business managers in the spun-off firms retained many advantages to get access to or be referred by governmental officials, many of whom were their former colleagues in the government. Therefore the organizational 
dormant report chain - being a spin-off from the government or another SOE constitutes a governmental tie channel.

The governmental tie channel of spin-offs is more likely to be present among SOEs, rather than NSOEs. The phenomenon of the government/SOE spin-offs emerged in the early 1980s, during which the Chinese government was reluctant to give up ownership of the spun-off firms. Although starting from the late 1990s, the government allowed for the privatization of SOEs, the sheer number of SOEs in China dictated that only a small portion of spun-off SOEs had completed privatization. The incessant debate within the Chinese government about how to prevent the cheap selling of public assets further restricted the scale of privatization of SOEs. Thus we hypothesize:

Hypothesis 2 (H2): SOE managers will have more government organizational channels than will NSOE managers.

\section{Social Categories and Governmental Tie Distribution}

One may infer that the relationship between ownership type and governmental tie distribution in China is straightforward because the notion that the number of governmental ties should be greater for SOEs than for NSOEs is too intuitive. This is not the case. Two previous studies (Park \& Luo, 2001; Xin \& Pearce, 1996) oppose this intuition. These studies maintain that because Chinese NSOEs lack formal institutionalized support from the government, NSOEs confront more difficulties in garnering resources as well as political backing, protection and legitimacy than SOEs. Building on the 'lack of structural support' notion, NSOE managers are proposed to have more governmental ties than SOE managers, because the former group has to 'cultivate personal connections to substitute for reliable government and an established rule of law' (Xin \& Pearce, 1996: 1642). While they identify some needs of NSOE managers to possess social ties to government officials, we suggest that the previous two studies are one-sided because they do not compare the needs of NSOE managers with those of SOE managers. SOEs mangers may also have high demands for governmental ties for a variety of reasons, such as political protection and promotion in the governmental hierarchy. We argue that a comparison of the needs is theoretically complicated to enumerate and empirically challenging to exhaust.

We suggest that it is problematic to explain the tie distribution issue by comparing needs, and a more fruitful approach is to compare the number of core governmental tie channels. Because core channels contain the range of opportunities for new social relationships, they are the direct antecedents of tie variability across social actors. The kind of 'opportunities facilitate social relationships' argument is deeply rooted in sociological research (Blau, 1977; Feld, 1981). We deepen this line of argument and propose that SOE managers possess more governmental 
ties than NSOE managers because NSOE managers are more likely to be deprived of core tie channels owing to an exogenous force - the Chinese institutional framework. We view the core governmental tie channels directly erected by the Chinese government as the 'structural support' from the Chinese government: SOE managers, by virtue of their organizations' ownership by their employers, routinely contact governmental officials through these core governmental tie channels. If we identify and enter all tie channels as explanatory variables for social ties, social categories will not have incremental validity for social ties because tie channels are the prerequisite, and hence antecedents, for the emergence of social ties. When we cannot enumerate all tie channels and as a result only enter some tie channels as explanatory variables for social ties, social categories might have incremental validity for social ties because the incomplete set of tie channels only partially mediate the linkage between social categories and ego-network tie sizes (see Fig. 1).

Therefore, the examination of the mediating role of tie channels is complicated by the fact that tie channels, especially peripheral tie channels, are usually numerous and empirically difficult to exhaustively enumerate (Marsden, 2005). A question thus arises: How can we identify a parsimonious set of channels that mediate the relationship between the ownership type of the manager's firm and the ego-network size of the manager's governmental ties? We maintain the answer is to distinguish two concepts: social tie emergence and social tie distribution. While almost all tie channels can induce social tie emergence, a significant portion of peripheral tie channels are irrelevant to social tie distribution. For example, men and women both inherit their genetic linkages from their parents. Kinship - a membership channel leads to kinship ties but has no predictive validity for kinship tie distribution between men and women. As another example, some friendship tie channels, including being brought up in the same neighbourhood and attending the same school, pertain to friendship tie emergence, but not friendship tie distribution. These examples hint that tie channels irrelevant to tie distribution share one common feature: They are peripheral tie channels in the sense that they are mostly shielded from the influence of the societal institutional framework.

How can we identify the parsimonious set of tie channels that possess predictive validity for tie distribution? We adopt the structural view of tie distribution: The characteristic of social ties possessed by a social group is accounted for by the societal situation in which the social group operates (Moore, 1990). This parsimonious set of tie channels mostly includes core channels, which are deeply influenced by the societal institutional framework. The framework confers distinct opportunities for and constraints on the formation of tie channels (Blau, 1977; Blau \& Schwartz, 1984). These tie channels are formed in the evolution of the societal institutional framework. Specific to our analysis, ownership types do not directly influence the extensiveness of governmental ties per se; rather the Chinese institutional framework is responsible for governmental tie distribution. 
Because the Chinese framework overwhelmingly endorses the power base of the Chinese government, an analogy for the role of the Chinese framework in shaping governmental tie channels is an onion. When one onion is sliced in half, rings - governmental tie channels - surround the core of the onion - the Chinese government. Although there are many rings, the outer (peripheral) rings, such as being brought up in the same neighbourhood as a government official, are mostly removed from the influence of the Chinese government. However, the most inner (core) rings of the onion are the key institutions set up by the Chinese government for power consolidation. These rings represent the report chains through which the Chinese government reaches out to control different economic sectors and social strata. For example, the Chinese government itself creates governmental tie channels - CGP, PCGs, and CPPCGs - for the purpose of allowing future government officials and grass roots leaders from every economic sector and political faction to approach and support the government. These institutions, although they are not government organs per se, are the satellite institutions brought within the orbit of the government - the most dominant social actor of the Chinese institutional framework.

The evolution of the Chinese government creates other crucial government tie channels that favour SOE managers. The government takes care of downsized former officials by arranging jobs for them in SOEs. As another example, the Chinese institutional framework structures the organizational channels. Economic reforms necessitated a drastic evolution of the Chinese institutional framework. The reforms transformed the relationship between SOEs and the Chinese government, altering the relationship from SOEs' absolute subjugation to SOEs' freedom in self-management. The loosened relationship between SOEs and the government was best manifested by the occurrences of guakao, zhuguandanzwei, and former government spin-offs.

Therefore, we propose that the parsimonious set of core tie channels can be identified from the crucial by-products created in the trail of societal framework evolution: serving as the mediating mechanism linking the social background of the managers to the size of their government network ties:

Hypothesis 3 (H3): Membership and organizational channels will mediate the relationship between the owenership type of the manager's firm and the total number of government ties in the manager's social network.

\section{METHOD}

\section{Sample and Data Collection}

We conducted our survey from late 2003 to mid-2004 in a city with about seven million residents in mid-west China. A pilot mail survey was sent to 60 companies, among which 11 returned the questionnaires. The pilot survey was used to test the 
face validity of questionnaire items before we began our face-to-face interviews in the formal data collection.

Our firm population was 13,000 companies with at least 10 employees, which were registered with the city's Bureau of Statistics. Using the proportional allocation method, we randomly drew 250 firms from this firm population so as to match the industry distribution of our sample firms with that of the population (Yao, Li, Sue-Chan, \& Xi, 2009). Our first sample (denoted as sample A: $A_{1}, A_{2}, \ldots, A_{250}$ ) was the 250 firms. Next, we ranked all the firms in the firm population that belong to the same industry as a given firm, $A_{x}(0<x \leq 250)$, from the smallest to the largest according to the number of employees in them. We denoted the firm immediately after $A_{x}$ in this ranking as $B_{x}$ and included it in the second sample (denoted as sample B). Likewise, we denoted the firm immediately before $A_{x}$ in this ranking as $C_{x}$ and included it in the third sample (denoted as sample $C$ ). We interviewed the head of firm $A_{x}$, who was either the CEO or the chairperson in charge of daily operations (i.e., the $\mathrm{COO}$ ). We guaranteed the anonymity of the interview participants. When our interview request was declined by the head in firm $\mathrm{A}_{x}$, we interviewed the head in firm $\mathrm{B}_{x}$. When our request for firm $\mathrm{B}_{x}$ was also declined, we interviewed the head in firm $\mathrm{C}_{x}$. We completed interviews of 104, 76, and 65 heads in samples A, B, and C, respectively. For our target sample size of 250 we were short of five heads of firms. Consequently, we drew another sample of five firms that closely matched our sample requirements in terms of the number of employees and industry. Our interviews in the redrawn five firms were all successful, and our final sample size totalled 250 (Yao et al., 2009).

\section{Independent and Dependent Variables}

The Chinese government recognizes two types of SOEs: state-owned and collectively owned firms. Two dummies were created to serve as the independent variables for $\mathrm{H} 1$ and $\mathrm{H} 2$. State-ozened Firm was coded as 1 when the focal manager's employer was state-owned, and 0 otherwise. Collectively owned Firm was coded as 1 when the focal manager's employer was a collective hybrid, and 0 otherwise. The omitted category is for all non-state firms.

To test $\mathrm{H} 1, \mathrm{H} 2$, and $\mathrm{H} 3$, we measured the focal manager's memberships in the CCP, PCC, and CPPCC, respectively ( $0=$ no membership, $1=$ membership). We also measured whether the focal manager had prior government experience $(0=$ no; 1 = yes). The variable, No. of Membership Channels, was the sum of the focal manager's memberships and his/her government experience. This variable ranged from 0 (had no membership and no experience) to 4 (had memberships in CCP, PCC, and CPPCC, and government experience). Another variable, No. of Organizational Channels, took the value of three if the focal manager's firm possessed three characteristics - it is 'parked under' a government organ or another SOE, has a zhuguandanwei, and was spun-off from a government organ or another SOE. This 
variable took the value of two if the firm possessed two of the above characteristics, one if the firm had one characteristic, and zero if the firm had none.

The dependent variable for H3, Ego-Network Size of Governmental Ties, is the sum of the numbers of three types of governmental ties. The first type is the ties to officials from whom a given manager sought managerial advice. Government officials were defined as those who worked in the CCP committees, ministries, agencies, and the national-, provincial-, municipal-, and township-level governments. The second type is the ties to officials with whom the manager spent after-work time in social activities. We explained to the research participants that social activities varied from getting together for dinners, social chats, social functions, or mutual family visits to pursuing common interests and hobbies (e.g., golfing and attending the same night school). The third type is the ties to officials whom the manager regarded as most crucial for the survival and development of the manager's firm. The first two types are included because advice ties and friendship ties are among the most-researched social ties (e.g., Gibbon, 2004). The third type, resource ties, was chosen because the resources sanctioned by the Chinese government are critical for firm survival. A principal component analysis showed that the numbers of three types of ties loaded on only one component with the eigenvalue larger than 1 , and this component explained 68.29 percent of the variance.

\section{Control Variables}

Three firm-level controls were included: Firm Age indicated the age of the focal firm at the end of 2002; Firm Size was the logarithm of the focal firm's total assets; and the last control was Firm Industry. The Chinese government classifies industries into three broad sectors: (i) agriculture; (ii) manufacturing, mining, infrastructure, and building construction; and (iii) services. As no firm in our sample belonged to the first sector, we coded Firm Industry as one (zero) when the focal firm belonged to the second (third) sector. We further subdivided 250 firms into 20 sectors classified by the city's Bureau of Business Registry, and accordingly created one sector dummy for each sector. We found no change in our analysis results by replacing Fim Industry with the sector dummies. We used the Firm Industry dummy in the analyses for hypotheses testing.

Five individual-level control variables were also included. Because the pilot survey indicated that managers hesitated to reveal their exact ages, we measured Manager Age in bands $(1=25-30 ; 2=31-35 ; 3=36-40 ; 4=41-45 ; 5=46-50$; $6=51-55 ; 7=56-60 ; 8=60$ and above). Our sample contained no manager younger than 25 years. Manager Gender was coded as one (zero) for men (women). As social network studies often suggest that educational level is positively related to the extensiveness of social ties (Lin, Cook, \& Burt, 2001), the variable Manager Education Level was used to indicate the education attainment of managers $(1=$ primary 
school, $2=$ junior high, $3=$ senior high, $4=$ college, $5=$ undergraduate degree, $6=$ master's degree, $7=$ doctoral degree). The variable, Manager Prior Experience in $S O E$, was coded as one if the manager had worked in an SOE other than the focal firm, and zero otherwise. The last control variable, Manager Administrative Rank, was used to measure the rank of the manager in the Chinese government hierarchy. Affiliating with the Chinese government or a government-funded institute (e.g., universities, hospitals, etc.) earns a person a 'rank'. An undergraduate degree holder, for example, could be granted the rank of officer (in Chinese, $g u$ (股)) by the government because universities are government-funded institutions. Chinese society uses rank to gauge social status, and these ranks apply not only to SOE managers, but also to NSOE managers. Our participants' Manager Administrative Rank ranged from one (officer) to eight (vice provincial governor and above).

The main effects hypotheses $(\mathrm{H} 1$ and $\mathrm{H} 2$ ) were tested with simple regression analysis with all control variables entered in the first step. The mediation hypothesis (H3) was tested using hierarchical linear regression using the procedure recommended by Baron and Kenny (1986). This procedure requires three regression equations, described in the next section, to test the three essential conditions supporting a meditation model. To minimize multi-collinearity effects (Aiken \& West, 1991), the independent and mediating variables were centered.

\section{RESULTS}

Table 1 shows the means, standard deviations, and Pearson's correlations of all the variables. The largest correlation is below 0.53, causing few concerns about the multi-collinearity problem. Models 1 and 2 of Table 2 report the results of two OLS regressions, whose dependent variables are No. of Membership Channels and $N$. of Organizational Channels, respectively. State-owned Firm and Collectively ozened Firm in both models have significantly positive coefficients (at least $\mathrm{p}<0.05$ ), providing support for $\mathrm{H} 1$ and $\mathrm{H} 2$. Thus we found that SOE managers possess more membership channels than NSOE managers and SOEs possess more organizational channels than NSOEs. Because No. of Membership Channels and No. of Organizational Tie Channels are count numbers, we reran the data by using the standard count number analysis - negative binomial regression. The negative binomial regression results, available upon request, are consistent with the OLS analyses.

Several control variables are significant in Models 1 and 2. As indicated by the coefficient of Firm Size in Model 1, managers in larger firms had more membership channels $(p<0.001)$. Older managers, as indicated by Manager Age in Model 1, possessed more individual tie channels $(\mathrm{p}<0.01)$. Models 1 and 2 indicate that a manager with higher administrative rank had more membership and organizational channels (at least $\mathrm{p}<0.01$ ).

Model 3 includes all the control variables, along with Collectively ozened Firm, State-owned Firm as independent variables and Ego-Network Size of Governmental Ties as 


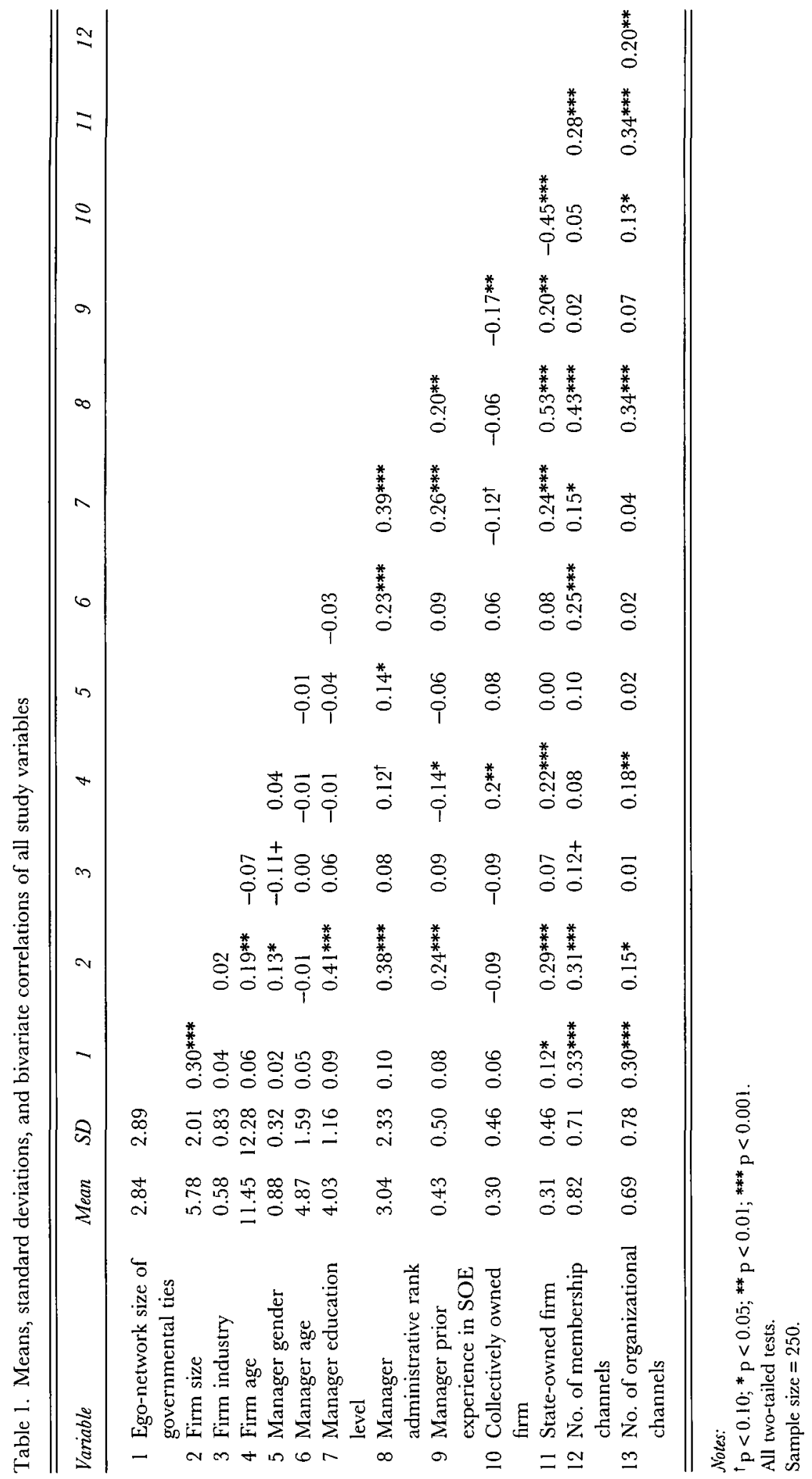

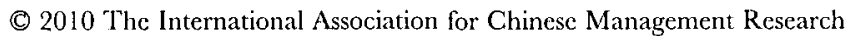




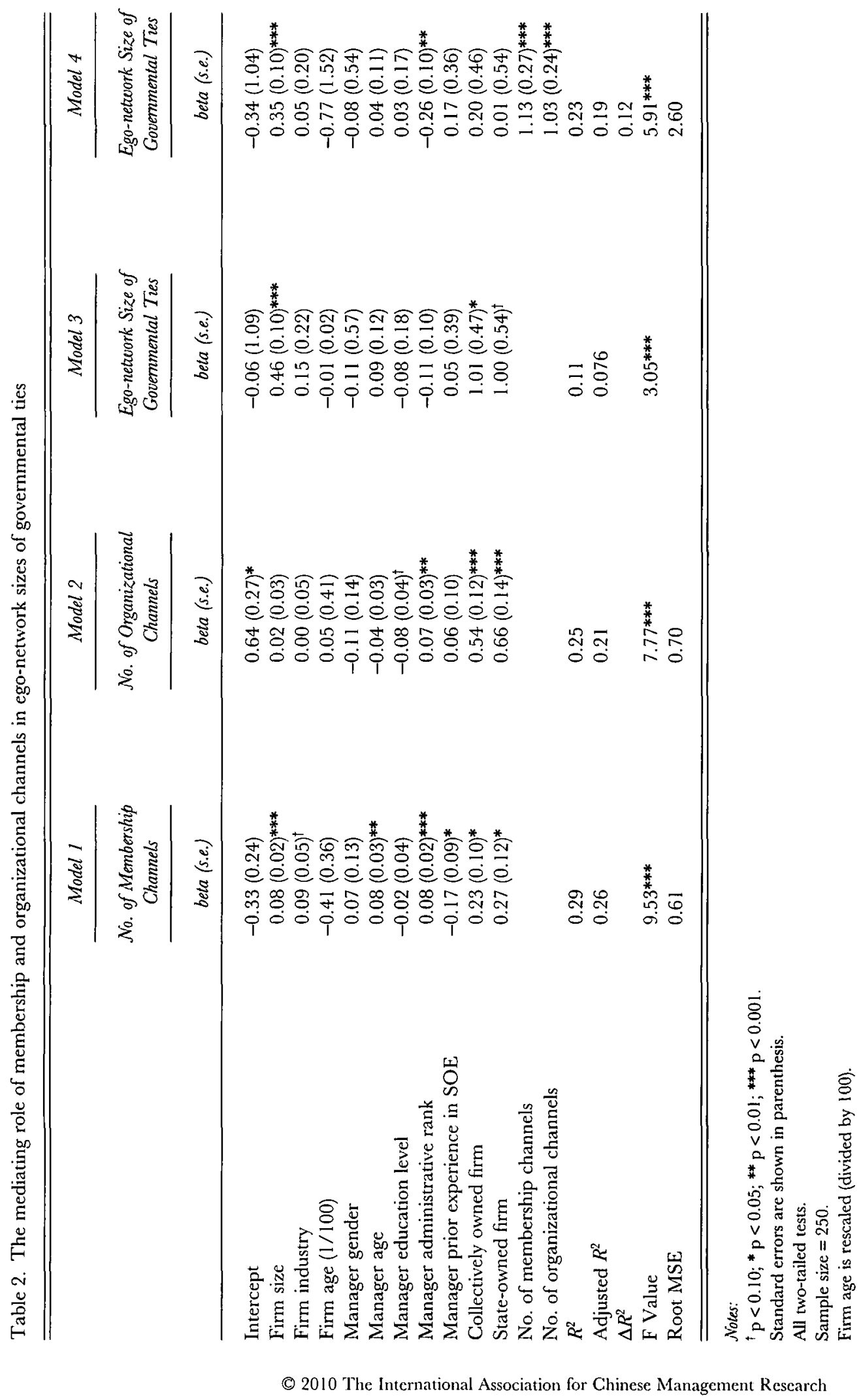


the dependent variable. Model 4 adds the two mediators, No. of Membership Channels

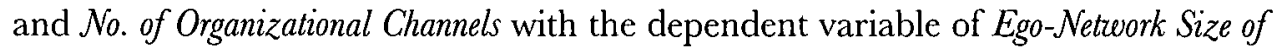
Govermmental Ties. This dependent variable is positively related to State-owned Firm $(p<0.10)$ and collectively owned Firm $(p<0.05)$ in Model 3 and it is also positively related to the two mediators in Model 4 (both $\mathrm{p}<0.001$ ). Model 4 is a significant improvement over Model $3\left(\Delta R^{2}=0.12 ; \mathrm{p}<0.001\right)$. After the two mediators are entered into the regression in Model 4, the two independent variables, ownership types, are no longer significant. This result indicates that the number of core governmental tie channels completely mediates the relationship between ownership types and ego-network size. The combined results in Models 3 and 4 provide support for $\mathrm{H} 3$.

\section{DISCUSSION}

Our study strives to reconcile the conundrum created by the network literature and the tie distribution issue. The network literature states that a given social network is a self-generated engine capable of self-producing social ties. The implication is that social categories can change disadvantageous, uneven ego-network sizes and make them even or advantageous. Yet, tie distribution is an issue because social categories maintain uneven ego-network sizes even though disadvantaged social actors can act to remedy their deficiencies in social ties. To bridge these conflicting views, our attention is directed to the societal institutional framework, as the exogenous force that shapes tie distribution. Our analysis shows that one specific feature of the Chinese institutional framework, which facilitates the domination of government in social, economic, and political affairs in Chinese society, plays an important role in shaping the ego-network sizes of Chinese managers' governmental ties. In particular, the Chinese institutional framework facilitates social stratification that divides managers into two social categories - SOE managers and NSOE managers, heightens the criticality of governmental ties for Chinese managers' economic pursuits, and confers more core governmental tie channels on SOE managers than on NSOE managers. In short, the ego-networks of governmental ties are derived from core societal institutions. We theoretically argue and empirically demonstrate that core governmental tie channels mediate the relationship between social categories and ego-network sizes.

Our study contributes to the network literature in several ways. First, we highlight the pivotal role of a society's institutional framework, pinpointing the farreaching impact of this relatively under-researched exogenous force in shaping the distribution of social ties. Our focus is on external factors in the quest for an answer to, 'Where do social ties come from'? We maintain that the overall repudiation of social category in particular and societal institutional framework in general in recent network studies has prematurely turned researchers away from specifying the base root of social capital deprivation. Our study shows that in a society, certain 
social groups are equipped by the societal institutions with more core social ties, possibly at the expense of other social groups.

Second, our study builds upon prior social category research that explains the problem of uneven ego-network sizes. We extend this line of research by shifting our focus from individual categories, such as gender and race (Portes \& Sensenbrenner, 1993), to organization-level categories, the ownership types of firms. In this sense this study thus bridges the macro-micro gap between the organizationlevel ownership types with individual-level social tie distribution. We propose that tie channels are the mediator that bridges the macro-micro gap. Furthermore, although prior social category research revealed the phenomenon of uneven tie distribution, our study extends this line of research by explicating the societal institutional framework as an important cause.

Third, our study depicts a 'powerless' image of individual managers. We show that NSOE managers' human agency usually is not enough to overcome their disadvantages stemming from their peripheral status in the Chinese institutional framework. The forces that determine the tie distribution problem - the uneven ego-network sizes across members of different social categories - are largely beyond the remedy of individual actions. Rather, the tie distribution problem is controlled by the overall actions of individuals working collectively as a society. The societal institutional framework dictates the emergence of salient social categories, and it distributes more core tie channels to members of one social category, and withholds core tie channels to members of another social category.

Fourth, we differentiate between tie channels and ties. Without the presence of tie channels, ties cannot be formed. Previous research (e.g., McPherson \& Rotolo, 1996) has neglected to make this separation and we argue that this is an important distinction because it permits the identification of the ways by which ties can be formed. The importance of this distinction can be illustrated by the case of two individuals who have the aim of purchasing as many pieces of clothing as they can. Individual A goes to a department store but individual B goes to specialty clothing stores (e.g., stores that sell only outerwear, stores that sell only innerwear, stores that sell only shirts, etc.). The choice of clothing available to individual A would be limited (e.g., only 30 different shirts from which to choose) when compared with the choices available to individual B (e.g., 300 different shirts from which to choose). Individual B would end up with a larger set of clothes due to the greater choices available than individual A, who goes only to one store. The stores, like tie channels, would determine the number of clothes (i.e., social ties) the individual could purchase. Knowledge about the number, type, and location of specialty clothing stores would be available only to individuals, such as B, who have 'insider' knowledge (i.e., SOE managers) about these specialty clothing stores.

Fifth, we dispute two previous studies' (Park \& Luo, 2001; Xin \& Pearce, 1996) suggestion that NSOE managers have more governmental ties than SOE managers because Chinese NSOEs lack formal 'structural support' from the government; 
hence, NSOE managers have to cultivate governmental ties to compensate for their lack of structural support. We propose that these two studies fail to acknowledge the role of core governmental tie channels. We introduce the notion that the core governmental tie channels directly erected by the Chinese government are one key embodiment of 'structural support' from the Chinese government. SOE managers by virtue of their organizations' ownership by their employers, routinely contact governmental officials through these core governmental tie channels and have more government ties than NSOE managers. We posit that government ties

per se do not compensate for lack of structural support; structural support in the form of core governmental tie channels makes government ties possible.

\section{Limitations and Future Research Directions}

A possible limitation of our research is that our sample is drawn from a transitional economy and the generalization of our findings to other economic contexts warrants future verification. While we took care to draw a sample of managers employed in the population of SOEs and NSOEs in our research context, our results may be generalizable only to contexts that are under the influence of similar institutional frameworks. Most of the studies in the endogenous approaches were conducted in the West where societal institutional frameworks are not as statedominated. It is also a fruitful avenue to investigate social tie distribution in other research settings. In these future studies, the identification of core tie channels in a particular research setting can enrich our understanding of how the institutional embeddedness of social actors play a role in shaping the social actor's social capital. Future research, which can provide insights on what leads to skewed tie distributions in other societies, is useful for providing practical guidance for remedying disadvantaged social groups.

Another limitation is that our study revolves around the possible endogeneity problem of our data. Our survey measured all variables at the same point in time. It is possible that managers acquired some membership channels before their managerial appointments. Although we could not rule out this possibility, we analysed whether this possibility may severely affect our results. We have no clear information to suggest that people's memberships in the CCP, PCC, and/or CPPCC will lead these people to more likely join SOEs rather than NSOEs, or vice versa. Many members CCP, PCC, and/or CPPCC are keen on starting their own NSOEs or joining existing NSOEs. In other words, it is unclear whether there is a significant positive relationship between government tie channels, such as the CCP, and employment by SOEs versus NSOEs. Future studies can examine longitudinal databases that track the trajectories of memberships and social ties.

A final limitation of our study is that it only measured the core tie channels, and our data did not capture peripheral tie channels. In our study, we focused 
on identifying the limited number of core tie channels. We based our identification of core tie channels from investigating the utmost important institution in the Chinese societal institutional framework - the CPP is the dominant force in China and it is the only ruling party in China. We do not suggest that future researchers should enumerate all social tie channels because doing so is theoretically interesting but practically impossible. Rather future research can focus on tie channels generated by secondary institutions in the Chinese societal institutional framework, such as Confucianism (Chai \& Rhee, 2010). These secondary institutions deeply affect social situations and life chances of social actors, and as a result, these institutions alter the distribution of social tie channels.

Importantly, future research should aim to integrate our study with the common notion in existing social network research that prior social ties, once started, tend to regenerate themselves in the future. We fully acknowledge this notion, but we speculate that the societal institutional framework interplays with this regenerative tendency. Although members of certain social categories that are disadvantaged by the societal institutional framework are able to start some social ties through the limited number of social tie channels, we speculate that the societal institutional framework may hamper the maintenance of these ties, and thus dampen the regenerative tendency of these social ties. In contrast, social ties started by members of advantageous social categories may enjoy a lower maintenance cost. Our snap-shot dataset does not allow us to investigate the longitudinal interplay between the institutional framework and social networks' regenerative tendency. We propose that future longitudinal studies are warranted to disclose the dynamic forces enforced by the societal institutional framework on the appearance, maintenance, and decay of social tie channels and social ties.

\section{Practical Implications}

A broad practical implication of our findings for managers conducting business in a society with which they are unfamiliar is to be aware that the societal institutional framework can hinder or enable their ability to enlarge their social capital. Specific to China, one of the largest recipients of foreign direct investments in the last decade, our study provides advice to foreign managers who work in NSOEs in China. These expatriates, in comparison with their Chinese business counterparts in SOEs, face daily challenges, as they are devoid of sufficient ties, at least at the early stage of their investments, with Chinese government officials. We provide practical advice to address these disadvantages. Disadvantaged foreign expatriates can improve their network web by establishing the right core tie channels, such as hiring managers with prior government work experience and memberships in core social institutes set up by the Chinese government. Similar to our earlier example of the two individuals who need to obtain a new set of clothes, expatriate managers need to be aware that there are many specialty stores rather than only one 
department store from which they can purchase their clothes. Chinese managers who work in NSOEs would also be well advised to note that the number of channel ties they possess also influences the number of government ties they have. To compensate for the disadvantage stemming from societal institutional framework, they too can work to identify and actively 'co-opt' core tie channels that are otherwise unavailable to them by, for example, employing individuals who are members of the CPPCC as consultants.

\section{GONGLUSION}

We argue that the correspondence between social categories and tie distribution highlights the impact of exogenous forces. The existing studies on tie distribution across social categories only allude to, but do not specify, the role of the societal institutional framework, an exogenous realm mostly beyond individual social actor's manipulation. We maintain that tie distribution is contingent upon the societal institutional framework: (i) it facilitates social stratification that divides social actors into different social categories; (ii) it heightens the criticality of certain types of social ties for social actors' economic pursuits; and (iii) it confers social actors of certain categories with more core tie channels.

The crux of our arguments - the societal institutional framework favours one category of managers over another, and equips them with more social tie conduits and consequently social ties, disputes the anti-categorical imperatives permeating in prior social network research. Although we acknowledge that social networks indeed possess a tendency to reproduce their prior ties, we argue that the appearance, re-appearance, fading, and ultimate disappearance of social ties in all social networks is neither a random, nor a self-regenerative process. Rather, this process is deeply sanctioned by the societal institutional framework, and as a result, members of certain social categories are provided with fewer social tie channels than members of other social categories. We conclude that social ties are rarely evenly distributed across social categories, but not because members of the disadvantaged social categories fail to put in enough effort to cultivate their fair share of social ties but rather the overarching societal institutions are amassed against their efforts.

\section{NOTES}

The first three authors contributed equally to the paper. This research is supported by a research grant awarded to Stan X. Li from the Social Sciences and Humanities Research Council of Canada (410-2009-1457), a Strategic Research Grant awarded to Christina Sue-Chan by the City University of Hong Kong, and two Grants (NSFC no. 70772108 and NCET-08-0448) awarded to Xiaotao Yao. We thank Royston Greenwood and Anne Tsui for their helpful comments on our earlier drafts. We also thank Anne Tsui for her insightful comments on the final draft of our manuscript.

[1] We thank one reviewer for this insightful observation. 


\section{REFERENCES}

Aiken, L. S., \& West, S. G. 1991. Multiple regression: Testing and interpreting interactions. Thousand Oaks, CA: Sage.

Baron, R. M., \& Kenny, D. A. 1986. The moderator-mediator variable distinction in social psychological research: Conceptual, strategic, and statistical considerations. Joumal of Personality and Social Psychology, 51(6): 1173-1182.

Batjargal, B. 2007. Comparative social capital: Networks of entrepreneurs and venture capitalists in China and Russia. Management and Organization Revieze, 3(3): 397-419.

Berkowitz, S. D., \& Wellman, B. 1988. Social structures: A netzeork approach. New York: Cambridge University Press.

Bian, Y. 1997. Bringing strong ties back in: Indirect ties, network bridges, and job searches in China. American Sociological Reviexe, 62(3): 366-385.

Bian, Y. 2002. Social capital of the firm and its impact on performance: A social network analysis. In A. S. Tsui \& C.-M. Lau (Eds.), The management of enterprises in the People's Republic of China: 275-298. Norwell, MA: Kluwer.

Blau, P. M. 1977. Inequality and heterogeneity. New York: The Free Press.

Blau, P. M., \& Schwartz, J. E. 1984. Crosscutting social circles: Testing a macrostructural theory of intergroup relations. Orlando: Academic Press.

Burt, R. S. 1986. Comment. In S. Lindenberg, J. S. Coleman \& S. Nowak (Eds.), Approaches to social theory: 105-107. New York: Russell Sage.

Burt, R. S. 1992. Structural holes: The social structure of competition. Cambridge, MA: Harvard University Press.

Chai, S.-K., \& Rhee, M. 2010. Confucian capitalism and the paradox of closure and structural holes in East Asian firms. Management and Organization Review, 6(1): 5-29.

Chen, W. 2007. Does the colour of the cat matter? The red hat strategy in China's private enterprises. Management and Organization Review, 3(1): 55-80.

China National Bureau of Statistics 2009. China statistical yearbook. Beijing: China Statistics Press.

Davis, L. E., \& North, D. C. 1971. Institutional change and American economic growth. Cambridge, UK: University Press.

Dickson, B. J. 2003. Red capitalists in China: The party, private entrepreneurs, and prospects for political change. Cambridge, UK: Cambridge University Press.

DiMaggio, P. J., \& Powell, W. W. 1983. The iron cage revisited: Institutional isomorphism and collective rationality in organizational fields. American Sociological Reviezw, 48(2): 147 160.

Doreian, P., \& Stokman, F. N. 1997. Evolution of social networks. Amsterdam: Gordon and Breach Publishers.

Emirbayer, M., \& Goodwin, J. 1994. Network analysis, culture, and the problem of agency. American Journal of Sociology, 99(6): 1411-1454.

Entwisle, B., Faust, K., Rindfuss, R. R., \& Kaneda, T. 2007. Networks and contexts: Variation in the structure of social ties. American Joumal of Sociology, 112(5): 1495-1533.

Feld, S. L. 1981. The focused organization of social ties. American Joumal Of Sociology, 86(5): 1015-1035.

Friedland, R., \& Alford, R. R. 1991. Bringing society back in: Symbols, practices and institutional contradictions. In W. W. Powell \& P. J. DiMaggio (Eds.), The neze institutionalism in organizational analysis: 232-263. Chicago, IL: University of Chicago Press.

Galaskiewicz, J., \& Burt, R. S. 1991. Interorganization contagion in corporate philanthropy. Administrative Science Quarterly, 36(1): 88-105.

Gibbon, D. E. 2004. Friendship and advice networks in the context of changing professional values. Administrative Science Quarterly, 49(2): 238-262.

Gilbert, D. L., \& Kahl, J. A. 1993. The American class structure : A neze synthesis (4th ed.). Belmont, CA: Wadsworth Pub. Co.

Granovetter, M. S. 1973. The strength of weak tics. American Joumal of Sociology, 78: $1360-1380$.

Granovetter, M. S. 1985. Economic action and social structure: The problem of embeddedness. American Journal of Sociology, 91(3): 481-510. 
Gulati, R., \& Gargiulo, M. 1999. Where do interorganizational networks come from? American Journal of Sociology, 104(5): 1439-1494.

Hitt, M. A., Ahlstrom, D., Dacin, M. T., Levitas, E., \& Svobodina, L. 2004. The institutional effects on strategic alliance partner selection in transition economies: China vs. Russia. Organization Science, 15(2): 173-185.

Ibarra, H. 1993. Personal networks of women and minorities in management - A conceptualframework. Academy of Management Reviez, 18(1): 56-87.

Kilduff, M., \& Tsai, W. 2003. Social networks and organizations. London, UK: Sage.

Li, D. D. 1998. Changing incentives of the Chinese bureaucracy. American Economic Reviez, 88(2): 393-397.

Li, S. X., \& Rowley, T. J. 2002. Inertia and evaluation mechanisms in interorganizational partner selection: Syndicate formations among U.S. investment banks. Academy of Management Joumal, 45(6): 1104-1119.

Lin, N. 1999. Social networks and status attainment. Annual Review of Sociology, 25: 467487.

Lin, N., Cook, K. S., \& Burt, R. S. 2001. Social capital: Theory and research. New York: Aldine de Gruyter.

Marsden, P. V. 1993. The reliability of netowrk density and composition measures. Social Networks, 15: 399-421.

Marsden, P. V. 2005. Recent developments in network measurement. In P. J. Carrington, J. Scott \& S. Wasserman (Eds.), Models and methods in social network analysis: 8-30. Cambridge: Cambridge University Press.

Meyer, J. W., \& Rowan, B. 1977. Institutionalized organizations: Formal structure as myth and ceremony. American Journal of Sociology, 83(2): 440-463.

Milgram, S. 1967. The small-world problem. Psychology Today, 1: 62-67.

Moore, G. 1990. Structural determinants of men's and women's personal networks. American Sociological Revieve, 55(5): 726-735.

McPherson, J. M., \& Rotolo, T. 1996. Testing a dynamic model of social composition: Diversity and change in voluntary groups. American Sociological Revieze, 61(2): 179-202.

North, G. C. 1990. Institutions, institutional change and economic performance. Cambridge, UK: Cambridge University Press.

Park, S. H., \& Luo, Y. 2001. Guanxi and organizational dynamics: Organizational networking in Chinese firms. Strategic Management Joumal, 22(5): 455-477.

Peng, M. W. 2003. Institutional transitions and strategic choices. Academy of Management Review, 28(2): 275-296.

Portes, A. 1998. Social capital: Its origins and applications in modern sociology. Annual Revieze of Sociology, 24: 1-24.

Portes, A., \& Sensenbrenner, J. 1993. Embeddedness and immigration: Notes on the social determinants of economic action. American Journal of Sociology, 98: 1320-1350.

Reagans, R., Zuckerman, E., \& McEvily, B. 2004. How to make the team: Social networks vs. demography as criteria for designing effective teams. Administrative Science Quarterly, 49(1): 101-133.

Renzulli, L. A., \& Aldrich, H. 2005. Who can you turn to? Tie activation within core business discussion networks. Social Forces, 84(1): 323-341.

Scott, R. 2000. The changing world of Chinese enterprise: An institutional perspective. In J. T. Li, A. Tsui \& E. Weldon (Eds.), Management and organizations in the Chinese context: 59-78. New York: St. Martin's Press.

Silver, A. 1990. Friendship in commercial society: Eighteenth-century social theory and modern sociology. The American Joumal of Sociology, 95(6): 1474-1504.

Smith-Doerr, L., \& Powell, W. W. 2005. Networks and economic life. In N. J. Smelser \& R. Swedberg (Eds.), The handbook of economic sociology (2nd ed.): 379-402. Princeton, NJ: Princeton University Press.

Stinchcombe, A. L. 1965. Social structure and organizations. In J. G. March (Ed.), Handbook of organizations: 153-193. Chicago, IL: Rand McNally.

Sun, P., Wright, M., \& Mellahi, K. 2010. Is entrepreneur-politician alliance sustainable during transition? The case of management buyouts in China. Management and Organization Revieze, 6(1): 101-121. 
Uzzi, B. 1996. The sources and consequences of embeddedness for the economic performance of organizations: The network effects. American Sociological Review, 61(4): $674-698$.

Volker, B., \& Flap, H. 1997. The comrades' belief: Intended and unintended consequences of communism for neighbourhood relations in the former GDR. European Sociological Revieze, 13(3): 241-265.

Wasserman, S., \& Faust, K. 1994. Social netzork analysis: Methods and applications. Cambridge, New York: Cambridge University Press.

Westphal, J. D., \& Milton, L. P. 2000. How experience and network ties affect the influence of demographic minorities on corporate boards. Administrative Science Quarterly, 45(2): 366-398.

White, H. C., Boorman, S. A., \& Breiger, R. L. 1974. Social structure from multiple networks. I. Blockmodels of roles and positions. American Journal of Sociology, 81: 730-780.

Xin, K. R., \& Pearce, J. L. 1996. Guanxi: Connections as substitutes for formal institutional support. Academy of Management Joumal, 39(6): 1641-1658.

Yang, M. M.-h. 1994. Gifts, favors, and banquets: The art of social relationships in China. Ithaca, NY: Cornell University Press.

Yao, X., Li, S. X., Sue-Chan, C., \& Xi, Y. 2009. Structural replacement or structural inducement: Government ties of Chinese business executives. Canadian Joumal of Administrative Sciences, 26(1): 54-70.

Zhang, J., \& Keh, H. T. 2010. Interorganizational exchanges in China: Organizational forms and governance mechanisms. Management and Organization Revieze, 6(1): 123-147.

Zuckerman, E. W., \& Sgourev, S. V. 2006. Peer capitalism: Parallel relationships in the U.S. economy. American Journal of Sociology, 11 1(5): 1327-1366.

Stan Xiao Li (sxli@schulich.yorku.ca) is an associate professor of Strategic Management at the Schulich School of Business, York University. He received his Ph.D. in Strategic Management from the Rotman School of Management, University of Toronto. His publications have appeared in Administrative Science Quarterly, Academy of Management Joumal, Strategic Management Joumal, Organization Science, Organization Studies and other outlets. His current research focuses on relational pluralism and legitimacy propaganda.

Xiaotao Yao (yxt@mail.xjtu.edu.cn) is a professor at the School of Management, Xi'an Jiaotong University, China. He received his Ph.D. in Organizational and Strategic Management from Xi'an Jiaotong University. His current research interests are in related issues of social network, social capital, and inter-firm alliances in China's transition economy.

Christina Sue-Chan (csuechan@cityu.edu.hk) is at the Department of Management, City University of Hong Kong. She holds a Ph.D. in Organizational Behavior and Human Resource Management from the Rotman School of Management, University of Toronto. Her articles have appeared in Joumal of Management, Organizational Behavior and Human Decision Processes, and international journals, such as Applied Psychology: An International Review and International Fournal of Human Resource Management. Her research interests are related to motivation, creativity, human resource management, and leadership. 
Youmin Xi (ymxi@mail.xjtu.edu.cn), a professor of Management of Xi'an Jiaotong-Liverpool University, is the author or co-author of numerous articles and 20 books, and editor of several academic journals. His current research focuses on Hexie management theory, strategic management, and knowledge management.

Manuscript received: August 27, 2008

Final version accepted: July 1, 2010

Accepted by: $\quad$ Yanjie Bian 